TAYLOR, P. and R.F. KOES 1987. Scoter migration in southeastern Manitoba, 1975-1986. Blue Jay 45:166171.

THOMPSON, E.E. 1981. The birds of Manitoba. Proc. U.S. Natl. Mus. 13:457643.

TREMAINE, M.M. 1966. Saskatchewan revisited. Blue Jay 24:182-183.

VICKERY, P.D. 1988. Distribution and population status of the Harlequin Duck
(Histrionicus histrionicus) wintering in eastern North America. Wilson Bull. 100:119126.

18 WALTON, K. and D.I. MACLACHLAN 1978. Third record of a Harlequin Duck at Churchill, Manitoba. Blue Jay 36:45.

19 WEIR, R.D. 1988. The winter season, December 1, 1987-February 29, 1988, Ontario Region. Am. Birds 42:257.

\title{
URKEY VULTURES IN THE BIG MUDDY
}

ROL F. BJORKLUND, 3634 McCallum Avenue, Regina, Saskatchewan. S4S 0S5

uring the summer of 1989 two Turkey lture nests were found in the Big Iddy Valley of southern Saskatchewan the author and Martin Bailey. Both ts were located in rock outcroppings dry hillsides.

small cave under the lower edge of a f held the young at one site. Although ing into the cave was made difficult ause of the narrow opening and the ht incline leading to the flat dirt floor, tographs taken on 11 July 1989 show young covered in whitish fuzzy n with protruding black wing hers, black faces and whitish legs. landowner also photographed the ng when they emerged from the cave $r$ the end of July. He noted that he first them flying in mid-August and that remained in the area until the very weather began in December (pers. im.).

the second site the actual nest was found although a thorough search made of the rocky outcropping re the adults were ever vigilant. On a equent visit to the site on 25 August , two young were perched on top of the rocks and photos were taken. Their heads were black and legs gray. A few wisps of down still stuck out in one or two places on their necks and backs. These birds were capable flyers.

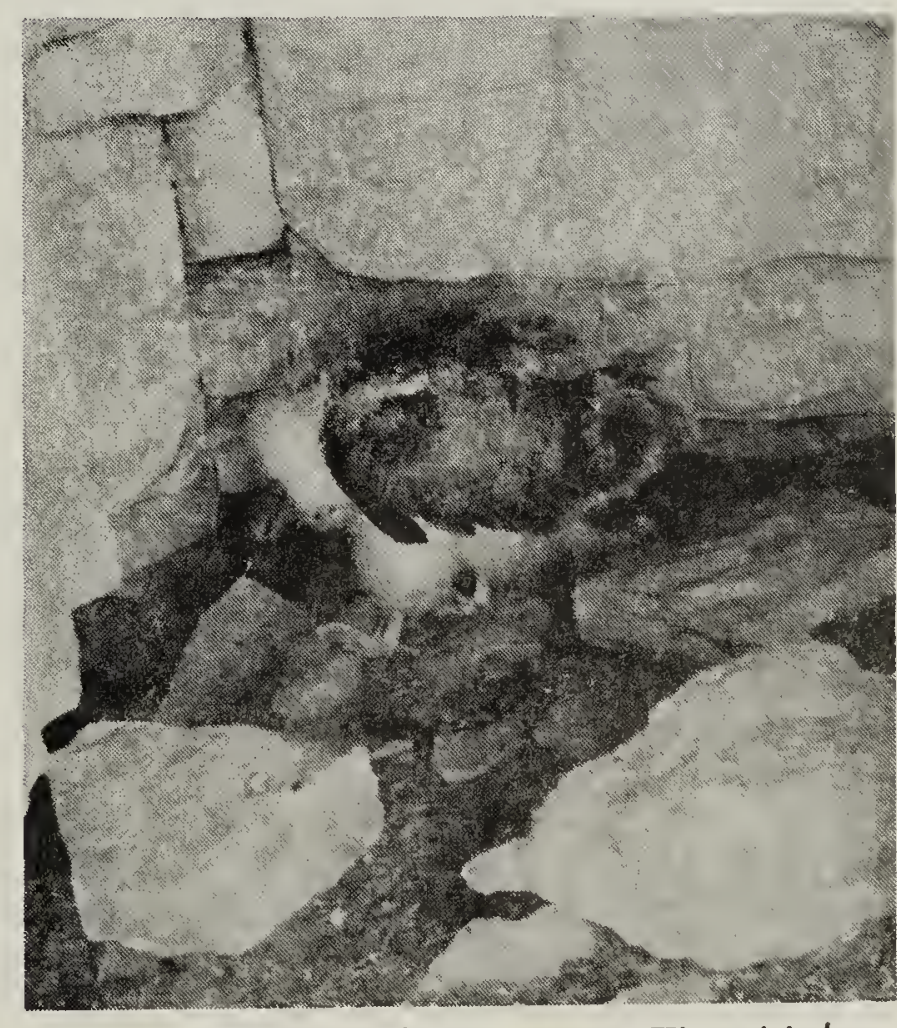

Young Turkey Vulture

Tim Lichter 